\title{
A brachiosaurid sauropod from the Late Jurassic Cañadón Calcáreo Formation of Chubut, Argentina
}

\author{
Oliver W. M. Rauhut* \\ Bayerische Staatssammlung für Paläontologie und Geologie, Richard-Wagner-Straße 10, D-80333 München, Germany, \\ and Museo Paleontológico Egidio Feruglio, Fontana 140, 9300 Trelew, Argentina
}

Received 4 February 2006, accepted 10 March 2006

Published online 17 July 2006

With 8 figures

Key words: Late Jurassic, Gondwana, South America, Dinosauria, Brachiosauridae.

\begin{abstract}
Fragmentary sauropod remains from the Late Jurassic (Tithonian) Cañadón Calcáreo Formation of Chubut, Argentinean Patagonia, are derived from a taxon of large size, but with very slender forelimbs. The characters of the caudal vertebrae, such as anteriorly placed neural arches, slender forelimbs, and large deltopectoral crest of the humerus indicate that this material represents the first brachiosaurid sauropod reported from South America. This occurrence confirms an almost global distribution of brachiosaurids in the Late Jurassic and thus indicates a rapid diversification and dispersal of this group after its origin, presumable in the late Middle Jurassic.
\end{abstract}

Schlüsselwörter: Oberer Jura, Gondwana, Südamerika, Dinosauria, Brachiosauridae.

\section{Zusammenfassung}

Fragmentarische Sauropoden-Reste aus der oberjurassischen Cañadón Calcáreo Formation (Tithon) in Chubut, argentinisches Patagonien, repräsentieren ein großes Taxon mit sehr schlanken Extremitäten. Die Charakteristika der Schwanzwirbel, wie etwa die vorne auf den Centra sitzenden Neuralbögen, schlanke Vorderextremitäten und der sehr gut entwickelte Deltopectoral-Kamm auf dem Humerus deuten darauf hin, dass es sich um den ersten Nachweis eines Brachiosauriden aus Südamerika handelt. Dieser Nachweis betont die offenbar fast globale Verbreitung dieser Gruppe im oberen Jura und deutet auf ein rasche Verbreitung und Diversifikation dieser Gruppe nach ihrer Entstehung, vermutlich im späten Mitteljura hin.

(C) 2006 WILEY-VCH Verlag GmbH \& Co. KGaA, Weinheim

\section{Introduction}

Ever since the great discoveries of Late Jurassic dinosaurs from the Morrison Formation of the western USA (e.g. Marsh 1896) and the Tendaguru Beds of Tanzania (Janensch 1914), this time period has been regarded as one of the "golden ages" of the dinosaurs. This is especially true for sauropod dinosaurs; their great diversity in both of these classic localities has led to the view that the Late Jurassic was the heyday of sauropod evolution (e.g. Bakker 1986), a view that has only recently been challenged by discoveries of abundant Cretaceous sauropods, mainly from the Southern Hemisphere (e.g. Upchurch 1998; Wilson 2002; Upchurch et al. 2004a). It is therefore rather surprising to note that our knowledge of Late Jurassic dinosaurs is actually based on few

* e-mail: o.rauhut@Irz.uni-muenchen.de 
localities; apart from the classic localities noted above, well-represented faunas are only known from the Upper Jurassic of Portugal (Antunes \& Mateus 2003) and China (Weishampel et al. 2004). In the Southern Hemisphere, the situation is even worse. Apart from the famous Tendaguru Beds, a Late Jurassic fauna from Gondwana has only been reported from the Kadzi Formation of the Zambesi Valley of Zimbabwe (Raath \& McIntosh 1987). However, the material recovered from this formation to date is extremely fragmentary (Raath \& McIntosh 1987), and the identification of most taxa is questionable.

Late Jurassic dinosaurs from South America have long remained virtually unknown, with the only record described being an isolated dorsal vertebra of a sauropod of probably Late Jurassic age from Colombia (Langston \& Durham 1955; Bonaparte 1981). Chong Diaz \& Gasparini (1976) mentioned some still undescribed dinosaur remains from the Upper Jurassic of Chile, and only a few years later Bonaparte (1979) reported the first Jurassic dinosaur fauna from South America, represented by abundant material (see also Bonaparte 1986a, 1996). These animals, the theropod Piatnitzkysaurus and the sauropods Patagosaurus and Volkheimeria, came from the Cañadón Asfalto Formation of the Argentinean province of Chubut, which is usually considered to be of Callovian-Oxfordian age. More recently, a further sauropod from the Jurassic of Chubut, supposedly also from the Caña- dón Asfalto Formation, was described as Tehuelchesaurus benitezii Rich et al., 1999. With Patagosaurus and Volkheimeria being basal, nonneosauropodan sauropods (Bonaparte 1986a, b, 1999; Wilson 2002; Upchurch et al. 2004a), and Tehuelchesaurus allegedly representing an omeisaurid (Rich et al. 1999; Upchurch et al. 2004a) this latest Middle to earliest Late Jurassic fauna would be strikingly different from the slightly younger fauna of Tendaguru (Aberhan et al. 2002). However, recent research indicates that the Cañadón Asfalto Formation is probably entirely Middle Jurassic in age (Rich et al. 1999; Volkheimer, pers. com 2002), and the rocks that have yielded Tehuelchesaurus can be referred to a different unit, the Cañadón Cacálreo Formation, which is Late Jurassic (Tithonian) in age (Proserpio 1987; Figari \& Courtade 1993; Rauhut 2003; Rauhut et al. 2005). Furthermore, new preparation and a new analysis of the type of Tehuelchesaurus indicates that this taxon represents a camarasauromorph and, most probably, a titanosauriform, rather than an omeisaurid (Salgado 2001; Rauhut 2002; Rauhut et al. 2005). Finally, recently a dicraeosaurid sauropod, Brachytrachelopan mesai Rauhut et al. 2005, was reported, also from the Cañadón Calcáreo Formation.

Recent fieldwork resulted in the recovery of more dinosaur remains from the Cañadón Calcáreo Formation (Fig. 1), including the material described here.

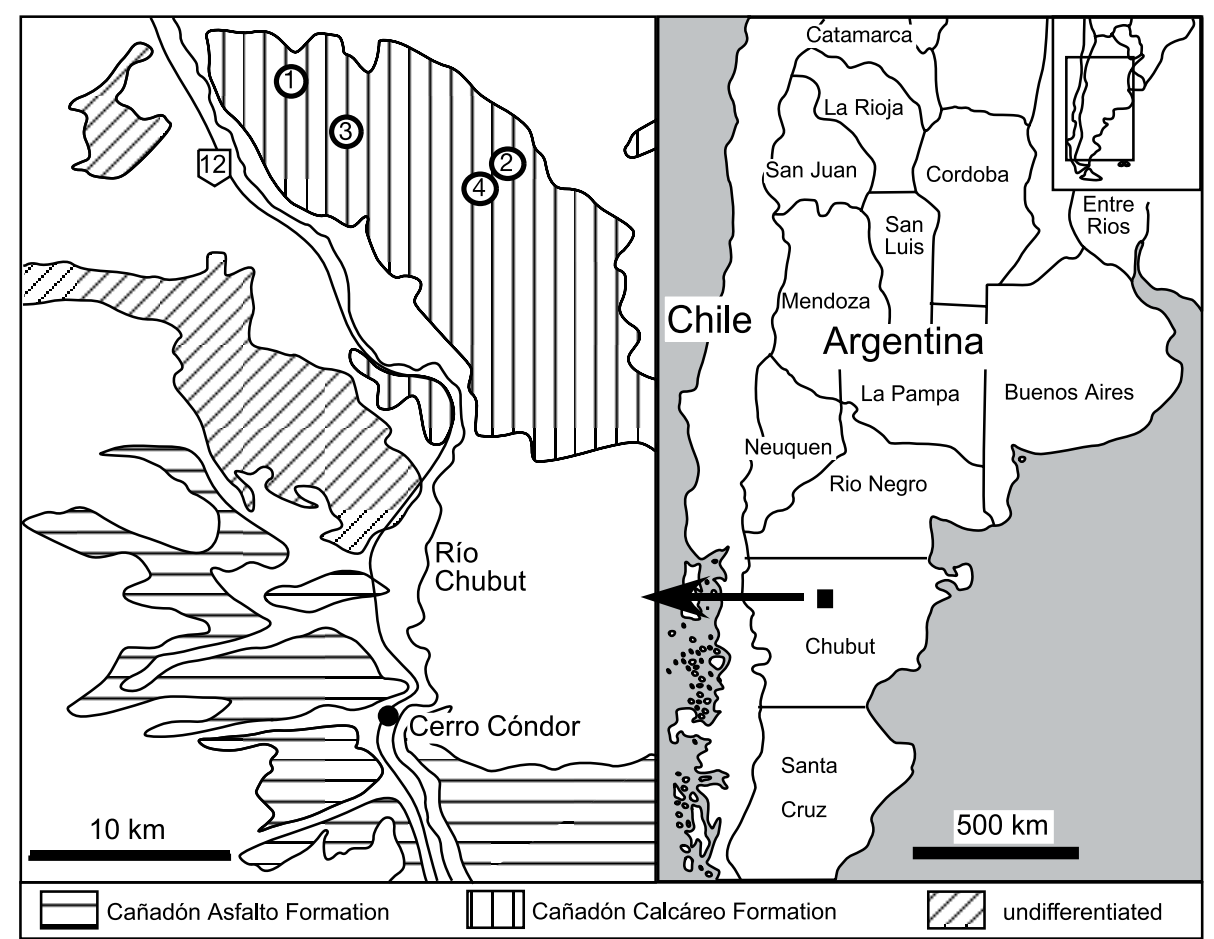

Fig. 1. Simplified geological map of the study area and geographical setting of the localities mentioned in the text. $\mathbf{1}$ - type locality of Tehuelchesaurus benitezii Rich et al., 1999; 2 - type locality of Brachytrachelopan mesai Rauhut et al., 2005; 3 - locality of the specimen figured in Fig. 2; 4 - localities of MPEF PV 3098 and 3099. 


\section{Geological and palaeontological context}

The Cañadón Asfalto Basin is an extensional hemigraben structure related with the initial break-up of Gondwana (Zambrano 1987; Figari \& Courtade 1993; Cortiñas 1996; Silva Nieto et al. 2002). The sediments usually included in the Cañadón Asfalto Formation (e.g. Turner 1983; Silva Nieto et al. 2003) represent the Jurassic continental sedimentary infill of this basin. As noted by Proserpio (1987) and especially Figari \& Courtade (1993), these sedimentary rocks can be divided into two distinct units, which, according to Figari \& Courtade (1993), are separated by a slight angular unconformity. The lower unit (Cañadón Asfalto Formation sensu stricto; Las Chacritas Member of Silva Nieto et al. 2003) consists mainly of lacustrine shales, marls, and limestones, with frequent basaltic intercalations and clastic layers (conglomerates and breccia) resulting from tectonic activities (Volkheimer in Tasch \& Volkheimer 1970; Turner 1983; Figari \& Courtade 1993; Cortiñas 1996; Cabaleri \& Armella 1999, 2005). This sequence represents the syn-rift phase of the Basin evolution (Figari \& Courtade 1993) and was greatly affected by synsedimentary tectonics and the Kimmeridgian phase of the Andean orogensis, so that the layers are frequently inclined, folded and faulted. These lacustrine sediments and their clastic intercalations have yielded a rich vertebrate fauna, including fishes, amphibians, turtles, squamates, crocodiles, mammals, pterosaurs, and dinosaurs (Bonaparte 1979, 1986a, 1996; Rauhut \& Puerta 2001; Rauhut et al. 2001, 2002; Rauhut 2003, 2005; Unwin et al. 2004; Martin \& Rauhut 2005).

The upper unit (Cañadón Asfalto Formation superior of Figari \& Courtade 1993; Puesto Almada Member of the Cañadón Asfalto Formation of Silva Nieto et al. 2003; Cabaleri \& Armella 2005; Cañadón Calcáreo Formation of Proserpio 1987) represents the post-rift phase of the Basin evolution (Figari \& Courtade 1993; Cortiñas 1996; Page et al. 1999) and is composed of lacustrine shales at the base, which are followed by clastic fluvial and overbank deposits as the basin infill prograded (pers. obs.; see also Figari \& Courtade 1993; Page et al. 1999). These rocks were deposited after the Kimmeridgian orogenetic phase and are thus much less tectonically disturbed than the sediments of the Cañadón Asfalto Formation sensu stricto. The age of this unit was long uncertain. Volkheimer (in Tasch \& Volkheimer 1970) and Bocchino (1978) considered the lacustrine shales to be Late Cre- taceous in age, whereas Turner (1983) assigned a late Middle - early Upper Jurassic age to these rocks. Musacchio et al. (1990) referred these layers to the Middle to Upper Jurassic, based on micropalaeontological evidence, but noted that a typical terminal Jurassic ostracode was missing in their samples. Figari \& Courtade (1993) discuss the age of this sequence in some detail and mention unpublished biostratigraphic evidence for an Early Cretaceous age. Finally, a so far unpublished radiometric dating of a tuff in the basal part of the section resulted in a Tithonian age (Koukharsky pers. com. 2002).

The lacustrine section of the Cañadón Calcáreo Formation has long been known for abundant and well-preserved fishes (Bordas 1943; Bocchino 1967, 1978; Cione \& Pereira 1987; López-Arbarello et al. 2002; López-Arbarello 2004). The fish fauna comprises at least two taxa of teleosts and one basal actinopterygian, presumably a coccolepid, plus several rarer, so far undescribed fishes (López-Arbarello 2004).

Tetrapods from the Cañadón Calcáreo Formation are so far only represented by undescribed turtle carapace fragments and saurischian dinosaurs. Theropods are only known from some unidentified teeth found in association with the type of Tehuelchesaurus benitezii (Rich et al. 1999) and fragmentary remains of a tetanuran (Rauhut 2002). Sauropods are the most abundant tetrapods and are known from some 20 specimens, most of which have not been excavated so far (Rauhut, unpublished data). Tehuelchesaurus benitezii is known from the type, an articulated partial postcranial skeleton (Rich et al. 1999), and probably another articulated, unexcavated partial skeleton. The dicraeosaurid Brachytrachelopan mesai is known from a fragmentary articulated skeleton (Rauhut et al. 2005). A further taxon of sauropod might be present, but is so far only represented by some large vertebral centra and a fragmentary scapula, which have not been collected. Finally, several specimens described here indicate the presence of a brachiosaurid titanosauriform.

Institutional abbreviations. MPEF: Museo Paleontológico Egidio Feruglio, Trelew, Argentina.

\section{Palaeontological Description}

Unfortunately, the Cañadón Calcáreo brachiosaurid is so far only represented by fragmentary material, so that a formal description has to await the discovery (or excavation) of more com- 


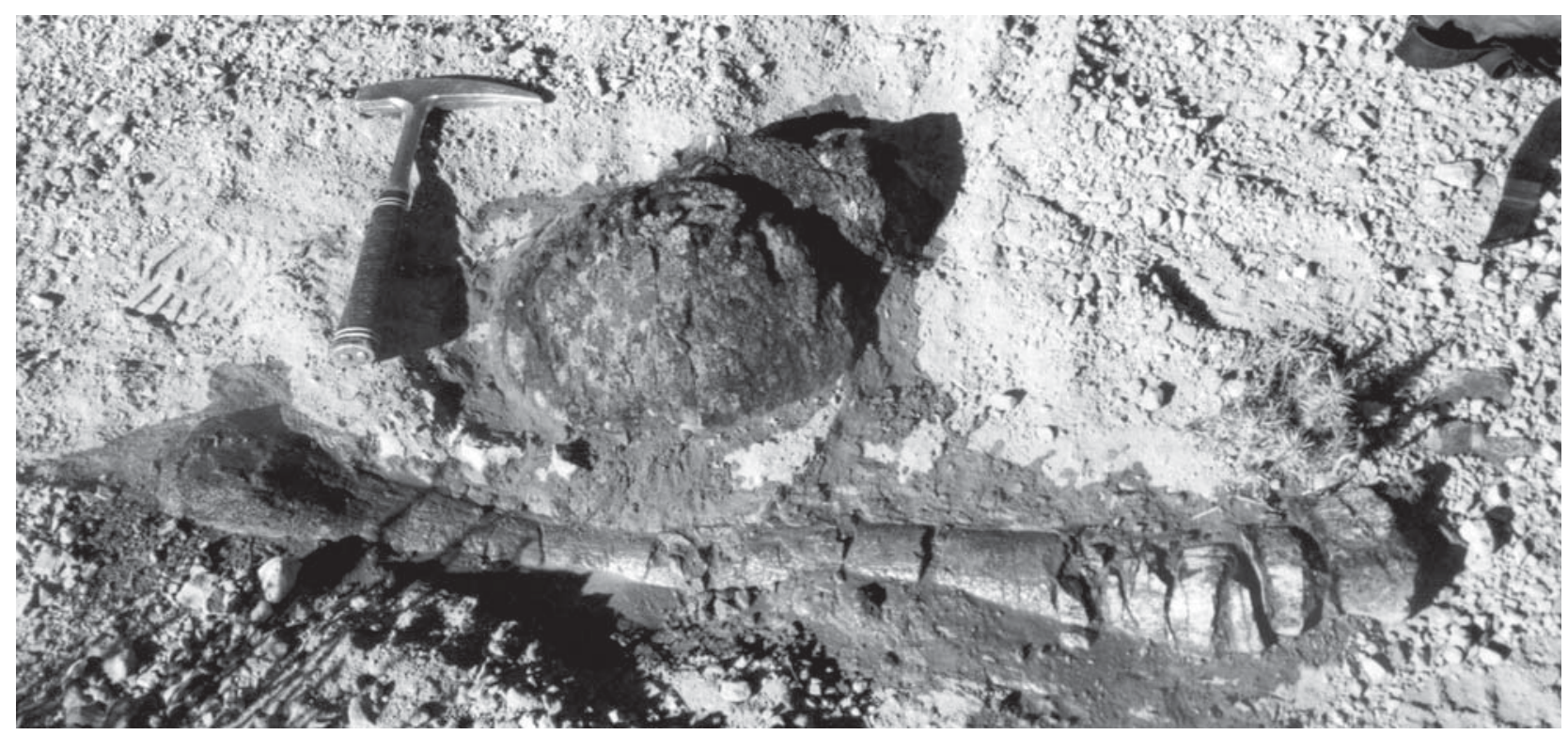

Fig. 2. Brachiosauridae indet. from the Cañadón Calcáreo Formation of Chubut, Argentina. Dorsal vertebra in anterior view (top) and radius (bottom) of an unexcavated partial postcranial skeleton.

plete remains. Furthermore, the three specimens discovered so far do not have overlapping elements. However, based on the characters exhibited, all of this material most probably represents a brachiosaurid sauropod, and thus might be referable to a single species, although this interpretation has to remain tentative until more complete remains have been discovered.

Unfortunately, one of the three specimens discovered still remains in the field. This specimen represents an associated fragmentary postcranial skeleton, including several dorsal vertebrae, elements of the pelvic girdle, and a radius (Fig. 2). The material is derived from a very large animal; the anterior face of an anterior dorsal vertebra is approximately $350 \mathrm{~mm}$ wide and the proximally incomplete radius is $970 \mathrm{~mm}$ long, with an estimated $10-15 \mathrm{~cm}$ missing, making the animal only slightly smaller than large Brachiosaurus brancai Janensch, 1914, from Tendaguru (Janensch 1950, 1961). The dorsal vertebrae are all exposed in anterior view; the centra are notably opisthocoelous and wider than high (Fig. 2). The most remarkable feature of the radius is the slenderness of the bone (Fig. 2); the least shaft diameter seems to be little more than $50 \mathrm{~mm}$, or less than $5 \%$ the length of the bone, making it even considerably more slender than the radius of $\mathrm{Bra}$ chiosaurus brancai (Janensch 1961).

The two other specimens were found in close proximity. One of them comprises an isolated humerus (MPEF PV 3098) that was found some $100 \mathrm{~m}$ apart from the second, a disarticulated to semiarticulated fragmentary postcranial skeleton
(Fig. 3). The second specimen (MPEF PV 3099) comprises 13 caudal vertebrae, five chevrons, several rib fragments, a partial right pubis, a shaft fragment of a large limb bone (probably a humerus), and some unidentified fragments. Ten of the caudal vertebrae were found in semiarticulation, together with several chevrons, but the rest of the material was scattered (Fig. 3). Both specimens were found on a flat area of lowangled outcrop with rather dense vegetation and were separated by an erosional cut. Although it seems quite possible that both specimens are derived from the same horizon and the distance does not necessarily preclude them from belonging to the same individual, there is no positive evidence that they do represent a single animal. However, the distal shaft fragment of a probable humerus found with MPEF PV 3099 closely matches MPEF PV 3098 in size and morphology.

All vertebrae of MPEF PV 3099 have damaged neural arches, and also the pubis is strongly damaged. The vertebrae recovered represent proximal to middle caudals (Fig. 4A-D). All vertebrae are slightly amphicoelous. The centra of the proximal caudals (Fig. 4A, B) are considerably higher than long and broadly oval, almost round in outline. In the first centrum, the neural canal is placed considerably lower posteriorly than anteriorly, so that the posterior articular surface is lower than the anterior surface, indicating that this is one of the first caudal vertebrae (Janensch 1950). No lateral or ventral excavations are present. Although there is a notable incision between the articular ends, ventrally the chevron 


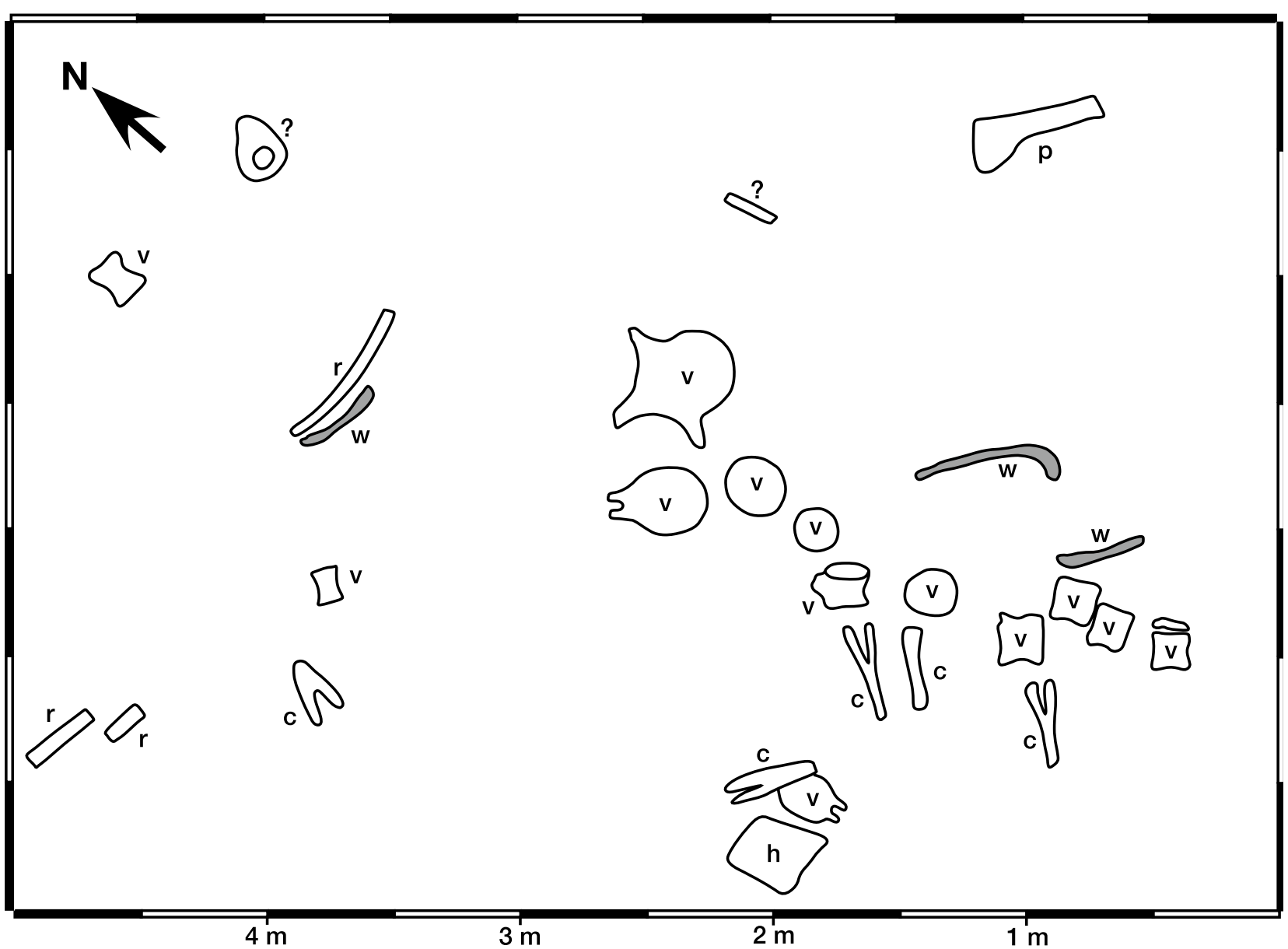

Fig. 3. Quarry map of the excavation site of the fragmentary brachiosaurid skeleton MPEF PV 3099 (locality DD 02) in the Cañadón Calcáreo Formation of Chubut, Argentina. Abbreviations: c - chevron; h - probable humeral fragment; p - pubis; $\mathbf{r}$ - rib fragment; $\mathbf{v}$ - vertebra; $\mathbf{w}$ - silicified wood.

facets are only weakly developed. Short, rod-like transverse processes with deep proximal bases are present on the posterior half of the centrum at its dorsal rim. The neural arch is simple, with a large, round neural canal, and lacking any lateral lamination. The prezygapophyses are small, oval and placed on short anterodorsal processes, whereas the postzygapophyses are found below the posterior base of the neural spine. The latter is broken, but its base indicates that it was a simple, anteroposteriorly short and transversely flattened rod.

Distally, the vertebral centra become relatively more elongate, which is mainly achieved by a rapid reduction of centrum height and width, rather than by an elongation of the centra (Fig. 4C, D). Although the centra are notably waisted, they are still massive. Especially the posterior chevron facets are marked as a notably anteroventral flexion of the ventral rim of the posterior articular surface. The transverse processes become more plate-like, but remain short and placed at the dorsal rim of the centrum. The neural arches become anteroposteriorly shorter in relation to the centrum and are placed on the anterior half of the centra. In their simplicity and the development of the zygapophyses, the neural arches correspond to that of the anterior caudal. However, the prezygapophyses are anteriorly rather than anterodorsally directed and the neural spine seems to be inclined posterodorsally (Fig. 4C).

In none of the preserved chevrons is the hemal canal bridged proximally (Fig. 4E, F), although, based on their position in the quarry (Fig. 3) and morphology, both proximal and mid-caudal chevrons are represented. The most proximal chevron preserved is probably the first chevron. In contrast to more distal elements, it is anteroposteriorly flattened and V-shaped. The more distal elements are $y$-shaped, with a large hemal canal and a rod-like ventral part. The proximal articular facets are slightly expanded and posterodorsally directed.

The left pubis of this specimen is only represented by a strongly damaged section of the 


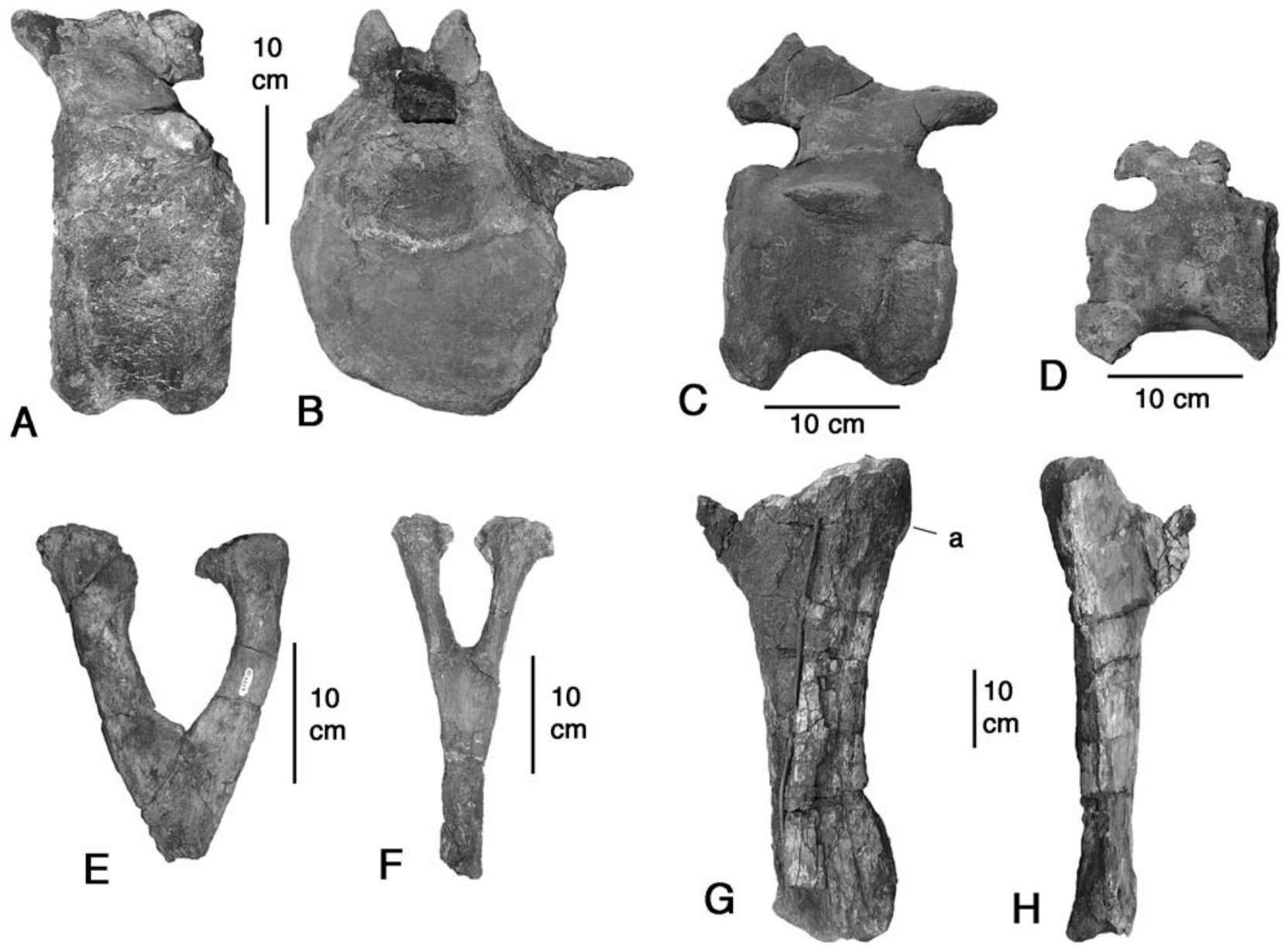

Fig. 4. Brachiosauridae indet. from the Cañadón Calcáreo Formation of Chubut, Argentina; MPEF PV 3099. A, B - proximal caudal vertebra in left lateral (A) and anterior (B) views; $\mathbf{C}$ - proximal mid-caudal vertebra in right lateral view; $\mathbf{D}$ - distal mid-caudal vertebra in right lateral view; $\mathbf{E}$ - first chevron in anterior view; $\mathbf{F}$ - mid-caudal chevron in anterior view; $\mathbf{G}, \mathbf{H}$ - left pubis in medial $(\mathbf{G})$ and anterolateral (H) views. Abbreviations: $\mathbf{a}$ - ambiens process of the pubis.

pubic shaft (Fig. 4G, H). It seems to have a slightly longer shaft than the pubes of Brachiosaurus and is notably less expanded distally. Proximally, the distal end of a low, step-like ambiens process is present, similar to the situation in Brachiosaurus (Janensch 1961), but unlike the more pronounced process in diplodocoids (e.g. Janensch 1961, Upchurch et al. 2004b), or the straight anterior margin in Tehuelchesaurus (Rich et al. 1999).

The left humerus MPEF PV 3098 (Fig. 5) is more than $160 \mathrm{~cm}$ long (distal end eroded) and thus represents a large sauropod, although it is notably smaller than large specimens of Brachiosaurus (Riggs 1904; Janensch 1961). The bone is straight and has an anteroposteriorly flattened shaft. The minimum shaft width is c. $23 \mathrm{~cm}$, or approximately $14 \%$ of the length of the bone. The articular ends are expanded, the proximal more so than the distal. However, with c. $53 \mathrm{~cm}$, or $33 \%$ of the total length of the humerus, it is considerably more slender than in most sauro- pods, with the exception of brachiosaurids (e.g. Janensch 1961). The proximal end is rounded in anterior or posterior view, with the medial part being slightly elevated in comparison with the lateral part. The medial side is also considerably more expanded than the lateral one, so that the medial margin of the humerus is notably concave, whereas the lateral margin is almost straight proximally. On the posterior side of the proximal end, slightly displaced medially from the midline of the bone, a notable bulge is found.

The deltopectoral crest extends over slightly more than one third of the length of the bone. It is anteriorly directed and high, in contrast to the reduced deltopectoral crests of most sauropods. Distally, the shaft expands gradually transversely on both sides. On the posterior side, there is a shallow, triangular, distally widening depression. Anteriorly, the eroded bases of the two small, medially placed intercondylar ridges that are typical for sauropods, are found. 


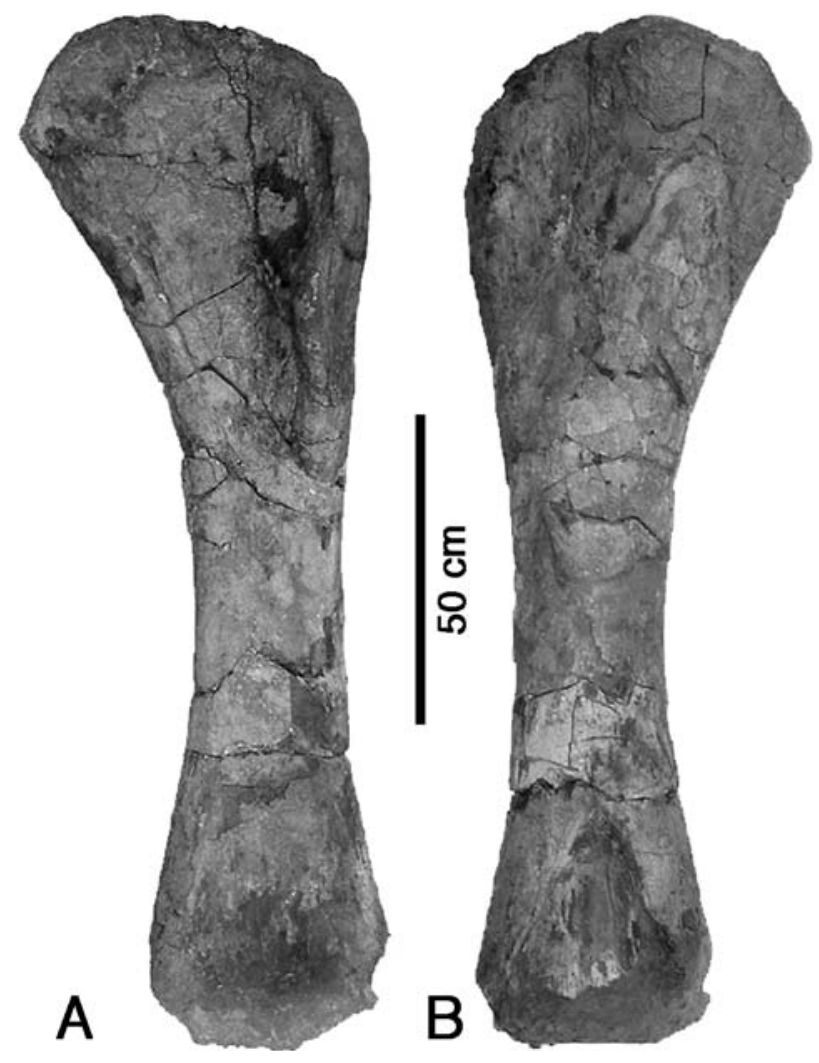

Fig. 5. Brachiosauridae indet. from the Cañadón Calcáreo Formation of Chubut, Argentina; MPEF PV 3098. Left humerus in anterior $(\mathbf{A})$ and posterior $(\mathbf{B})$ views.

\section{Discussion}

\section{The systematic affinities of the material}

All of the material shows characters that allow some inference concerning its systematic position within sauropods, indicating that all of it represents a basal titanosauriform.

The specimen MPEF PV 3099 shows proximally open hemal arches, which is a neosauropodan (Wilson 2002), or possibly camarasauromorph synapomorphy (Upchurch et al. 2004a). It furthermore exhibits one titanosauriform synapomorphy, the neural arches on the mid-caudal vertebrae anteriorly placed (Salgado et al. 1997; Upchurch 1998; Wilson \& Sereno 1998; Upchurch et al. 2004a). Within titanosauriforms, it lacks the derived feature of procoelous proximal caudal vertebrae found in titanosaurs (Wilson 2002), indicating that it represents a basal titanosauriform. The morphology of the pubis excludes the specimen from Tehuelchesaurus, especially the less expanded distal end, more pronounced ambiens process, and more poorly developed anterior and lateral expansion of the proximal end (Rich et al. 1999). The specimen shows one unusual character in common with
Brachiosaurus, a V-shaped first chevron that is anteroposteriorly flattened (Janensch 1950: figs 109, 123). In other sauropods, such as Camarasaurus (Osborn \& Mook 1921; McIntosh et al. 1996) or Apatosaurus (Upchurch et al. 2004b), this chevron is typically Y-shaped and does not differ significantly from the other chevrons, or is strongly modified, as in Jobaria (Sereno et al. 1999). However, first chevrons have been described in only few taxa, so more material is needed to establish this character as a brachiosaurid synapomorphy. Nevertheless, the caudal vertebrae and chevrons of MPEF PV 3099 agree with those of Brachiosaurus brancai in every detail, with the exception of the slightly more strongly posteriorly inclined neural spines in the mid-caudals (Janensch 1950).

The humerus MPEF PV 3098 is also very similar to the corresponding element in Brachiosaurus (Fig. 6; Riggs 1904; Janensch 1961), and shows the brachiosaurid synapomorphy of a large deltopectoral crest (Wilson \& Sereno 1998; Upchurch et al. 2004a). Further brachiosaur synapomorphies might be the slenderness of the bone, with its greatest transverse width (proximally) being less than $35 \%$ of the length of the element (Janensch 1961), and the proximally almost straight and little expanded lateral margin (Fig. 6).

To further test the systematic affinities of specimens MPEF PV 3098 and 3099, their data was added to the phylogenetic analysis of Wilson (2002), plus three additional characters (neural arches in mid-caudal vertebrae placed anteriorly on the centrum; first caudal chevron V-shaped; lateral side of proximal humerus straight) and one additional character state (ambiens process developed as low step, with anterior side of proximal pubis straight; additional state two to Wilson's character no. 189; see appendix for codings). An analysis of the matrix with PAUP 4.0b10 (Swofford 2003) resulted in 9 equally parsimonious trees with a length of 441 steps (CI 0.66; RI 0.8; RC 0.528). The topology of the consensus tree (Fig. 7) does not differ from the cladogram published by Wilson (2002: fig. 13A), other than in that MPEF PV 3098 and 3099 form an unresolved trichotomy with Brachiosaurus, thus supporting the referral of this material to the Brachiosauridae.

Finally, the unexcavated specimen exhibits the camarasauromorph synapomorphy of strongly opisthocoelous dorsal vertebrae (Upchurch 1998; Wilson 2002) and shares with Brachiosaurus and several other titanosauriforms the derived char- 

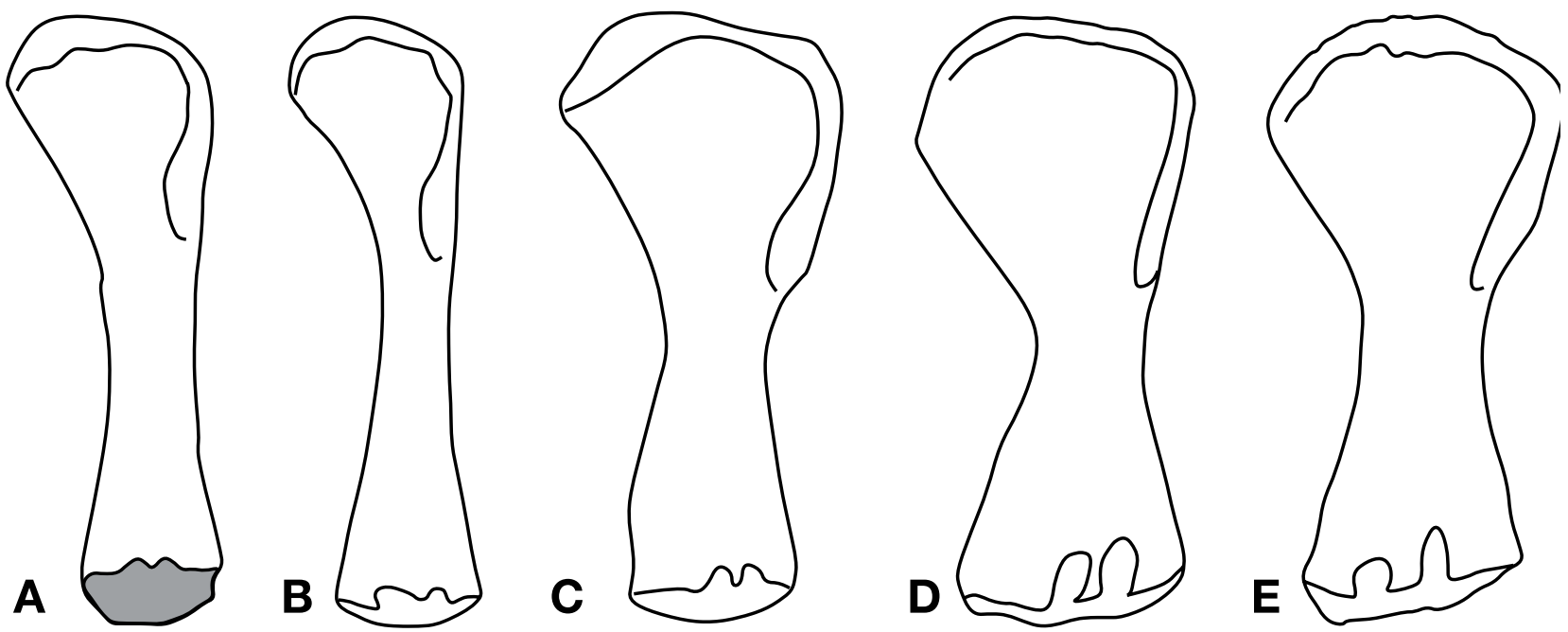

Fig. 6. Comparison of various sauropod humeri in anterior view. $\mathbf{A}$ - Brachiosauridae indet. from the Cañadón Calcáreo Formation; B - brachiosaurid Brachiosaurus brancai Janensch, 1914; C - basal camarasauromorph or titanosauriform Tehuelchesaurus benitezii Rich et al., 1999; D - basal titanosaur Janenschia robusta (Fraas, 1908); E - diplodocid Apatosaurus louisae Holland, 1915; all drawn to the same length. (B, D after Janensch 1961; C after MPEF PV 1125; E after Gilmore 1936).

acter of dorsal vertebral centra that are considerably wider than high (see Janensch 1950). Furthermore, the extremely long and slender radius might be another argument for a referral of this material to the Brachiosauridae.

Thus, the material described here gives strong indication of the occurrence of brachiosaurid sauropods in the latest Jurassic of southern South America. Given the great similarity of the available material to the African taxon Brachiosaurus brancai, the material might even be refer-

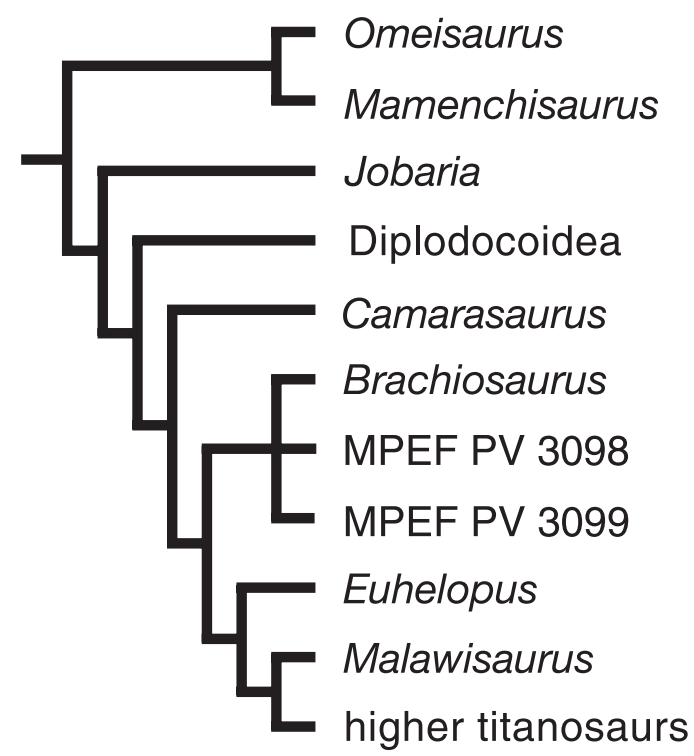

Fig. 7. Phylogenetic position of specimens MPEF PV 3098 and 3099 according to a phylogenetic analysis using an emended version of the matrix of Wilson (2002). For clarity of illustration, basal taxa have been omitted and several higher taxa (Diplodocoidea and higher titanosaurs) have been collapsed into a single OTU. See text and appendix for details of the analysis. able to the same genus, but more material is needed to confirm this.

\section{Implications for brachiosaurid evolution and biogeography}

With the discovery of a probable brachiosaurid from South America, this clade is now known from the Upper Jurassic of all continents that have yielded Late Jurassic dinosaurs with the exception of China (Fig. 8). In North America, they are known as rare faunal elements (Foster 2003) from the Kimmeridgian-Tithonian Morrison Formation with the species Brachiosaurus altithorax Riggs, 1903, and, possibly, Dystylosaurus edwini Jensen, 1985, although the latter might be referable to the former (Upchurch et al. 2004a). Records from Europe include the species Lusotitan atalaiensis (Lapparent \& Zbyszewski, 1957), from the Kimmeridgian-Tithonian of Portugal (Antunes \& Mateus 2003), and "Ornithopsis" humerocristatus Hulke, 1874, from the Kimmeridgian of England (Upchurch \& Martin 2003; Upchurch et al. 2004a). In the Southern Hemisphere, brachiosaurids are represented by Brachiosaurus brancai from the KimmeridgianTithonian of Tanzania (Janensch 1914), Brachiosaurus sp. from the Upper Jurassic of Zimbabwe (Raath \& McIntosh 1987), and probably the material described here from the Tithonian of Argentina.

The oldest known brachiosaurid is probably represented by material originally described as Ornithopsis leedsi Hulke, 1887, which is Callo- 


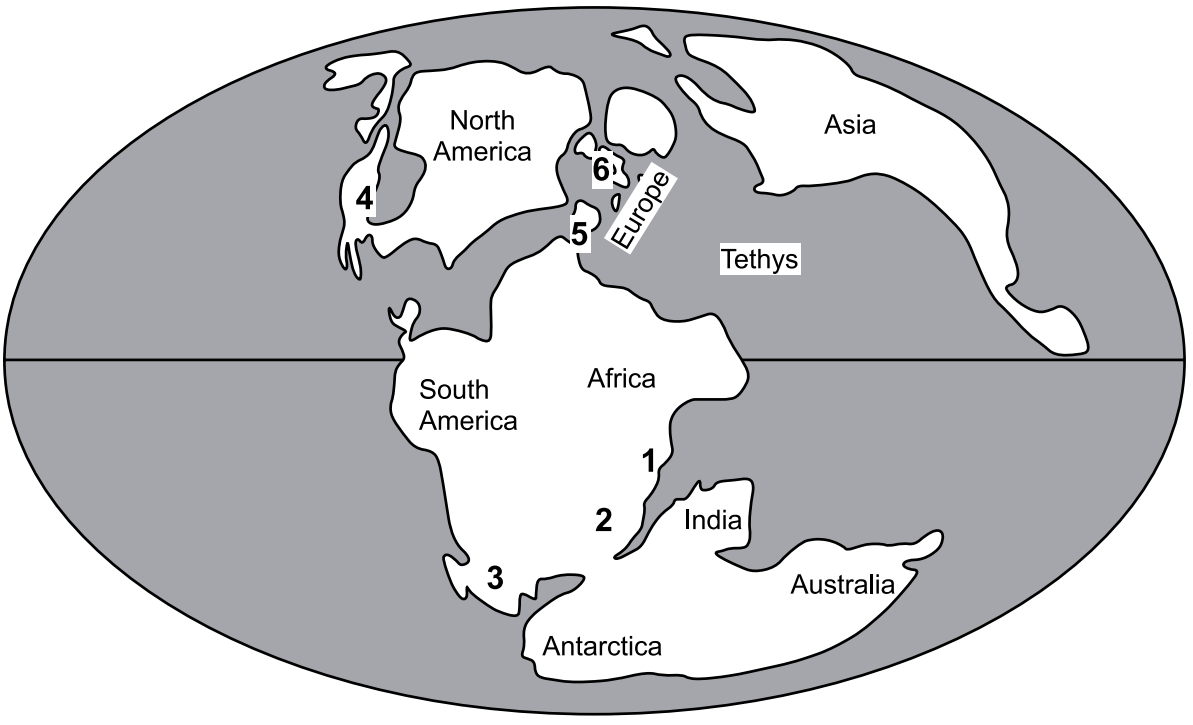

Fig. 8. Palaeogeographic map of the Upper Jurassic (Kimmeridgian) with known brachiosaurid occurrences marked. 1 - Tendaguru Beds (KimmeridgianTithonian): Brachiosaurus brancai; 2 - Kadzi Formation (unspecified Late Jurassic): Brachiosaurus sp.; 3 -Cañadón Calcáreo Formation (Tithonian): brachiosaurid indet.; 4 - Morrison Formation (Kimmeridgian-Tithonian): Brachiosaurus altithorax, ?Dystylosaurus edwini; 5 - Unidade Sobral (Tithonian): Lusotitan atalaiensis; $\quad \mathbf{6}$ - Kimmeridge Clay (Kimmeridgian): "Ornithopsis" humerocristatus. Map based on Smith et al. (1994).

vian in age (see Upchurch \& Martin 2003). Volkheimeria chubutensis from the Callovian of Argentina (Bonaparte 1979, 1986a) was referred to the Brachiosauridae by McIntosh (1990), but this material shows many primitive characters (Bonaparte 1986a, b, 1999), which indicate that it is a non-neosauropodan sauropod (Bonaparte 1986b, 1999; Rauhut 2002). Likewise, the referral of the Bathonian Lapparentosaurus madagascariensis Bonaparte, 1986b, from Madagascar to the Brachiosauridae (McIntosh 1990; Upchurch 1998) is doubtful (Upchurch et al. 2004a), and the very primitive dorsal neural arches of this taxon indicate that its affinities might even lie outside Neosauropoda (Bonaparte 1986b, 1999).

Thus, on the basis of the current fossil evidence, a late Middle Jurassic origin for brachiosaurids can be assumed, followed by a rapid diversification and dispersal leading to an almost global distribution in the Late Jurassic. This conclusion is further supported by palaeogeographic data.

Although abundant dinosaur remains have been found in the Upper Jurassic of China (Weishampel et al. 2004), no brachiosaurid remains have been reported from eastern Asia so far. Since eastern Asia was separated from the rest of Pangea by epicontinental seas from the second half of the Middle Jurassic (Bathonian or early Callovian) to the late Early Cretaceous (Smith et al. 1994; Upchurch et al. 2002), this indicates that probably brachiosaur origins, but certainly brachiosaur dispersal happened after this separation began (in the Bathonian at the earliest; Smith et al. 1994). This global distribution with the exception of eastern Asia is also consistent with general patterns of dinosaurian biogeography in the Jurassic that can be explained by vicariance due to the isolation of eastern Asia (Upchurch et al. 2002). On the other hand, the separation of North America/ Europe from the continents of the Southern Hemisphere, at least by epicontinental seas, was finalized towards the end of the Middle Jurassic (Smith et al. 1994; Upchurch et al. 2002; Ford \& Golonka 2003). Since it seems unlikely that greater megafaunal exchange between these two landmasses was possible after that time, this leaves only a rather narrow timeframe of some 6-7 Ma for the radiation and almost global dispersal of brachiosaurids in the Middle Jurassic (Gradstein et al. 2005).

\section{Conclusions}

Three fragmentary sauropod specimens from the Tithonian Cañadón Calcáreo Formation of Patagonia most probably represent a brachiosaurid, and thus constitute the first record of this clade from South America. Together with other skeletal evidence of Jurassic brachiosaurid distribution and the global palaeogeographic setting of these remains, this discovery indicates a rapid radiation and dispersal of this group in the late Middle Jurassic.

\section{Acknowledgements}

Special thanks are due to Dionide Mesa, who found specimens MPEF PV 3098 and 3099, and Patricia Navarro, who found the still unexcavated specimen. Daniel Mesa and his family and the Fernandez family are thanked for their hospitality during the fieldwork. Thanks are also due to the staff, 
especially Pablo Puerta, and volunteers of the Museo Paleontológico Egidio Feruglio in Trelew, Chubut, and to the preparators of this institution for the preparation of the remains. Wolfgang Volkheimer is thanked for insights into the geology of the of the continental Jurassic along the Chubut river, and Magda Koukharsky provided the information on the radiometric dating of the Cañadón Calcáreo Formation. This work greatly benefited from critical reviews by Kristina CurryRogers and Leonardo Salgado. Dieter Korn is thanked for handling the manuscript. Different stages of this project were financed by the German Academic Exchange Service (DAAD), Fundación Antorchas, BBC/Horizon, and the German Research Foundation (DFG), all of which is gratefully acknowledged. This is contribution No. 27 of the DFG Research Unit 533 "Biology of the sauropod dinosaurs. The evolution of gigantism".

\section{References}

Aberhan, M., Bussert, R., Heinrich, W.-D., Schrank, E., Schultka, S., Sames, B., Kriwet, J. \& Kapilima, S. 2002. Palaeoecology and depositional environments of the Tendaguru Beds (Late Jurassic to Early Cretaceous, Tanzania). - Mitteilungen aus dem Museum für Naturkunde Berlin, Geowissenschaftliche Reihe 5: 19-44.

Antunes, M. T. \& Mateus, O. 2003. Dinosaurs of Portugal. Comptes Rendus Palevol 2: 77-95.

Bakker, R. T. 1986. Dinosaur heresies. 481 pp., Zebra Books, New York.

Bocchino, A. 1967. Luisiella inexcutata gen. et sp. nov. (Pisces, Clupeiformes, Dussumieriidae) del Jurásico superior de la provincia de Chubut, Argentina. - Ameghiniana 4 (2): 91-100.

- 1978. Revisión de los Osteichthyes fósiles de la República Argentina. I. Identidad de Tharrias feruglioi Bordas 1943 y Oligopleurus groeberi Bordas 1943. - Ameghiniana 15 (3-4): 301-320.

Bonaparte, J. F. 1979. Dinosaurs: a Jurassic assemblage from Patagonia. - Science 205: 1377-1379.

- 1981. Inventario de los vertebrados Jurásicos de América del Sur. In Volkheimer, W. \& Musacchio, E. A. (eds). Cuencas sedimentarias del Jurásico y Cretácico de América del Sur, Volumen 2: 661-684, Comité Sudamericano del Jurásico y Cretácico, Buenos Aires.

- 1986a. Les Dinosaures (Carnosaures, Allosauridés, Sauropodes, Cétiosauridés) du Jurassique moyen de Cerro Cóndor (Chubut, Argentine). - Annales de Paléontologie 72: 247-289, 326-386.

- 1986b. The early radiation and phylogenetic relationships of the Jurassic sauropod dinosaurs, based on vertebral anatomy. In Padian, K. (ed.). The Beginning of the Age of Dinosaurs: 245-258, Cambridge University Press, Cambridge.

- 1996. Dinosaurios de América del Sur. 174 pp., Museo Argentino de Ciencias Naturales "Bernardino Rivadavia", Buenos Aires.

- 1999. Evolución de las vértebras presacras en Sauropodomorpha. - Ameghiniana 36 (2): 115-187.

Bordas, A. F. 1943. Peces del Cretáceo del Río Chubut (Patagonia). - Physis 19 (53): 313-318.

Cabaleri, N. G. \& Armella, C. 1999. Facies lacustres de la Formación Cañadón Asfalto (Caloviano-Oxfordiano), en la quebrada Las Chacritas, Cerro Cóndor, provincia del Chubut. - Revista de la Asociación Geológica Argentina 54 (4): $375-388$

- 2005. Influence of a biohermal belt on the lacustrine sedimentation of the Cañadón Asfalto Formation (Upper Jurassic, Chubut Province, Southern Argentina). - Geologica Acta 3 (2): 205-214.
Chong Diaz, G. \& Gasparini, Z. B. d. 1976. Los vertebrados Mesozoicos de Chile y su aporte geo-paleontológico.Actas del Sexto Congreso Geológico Argentino 1: 45-67.

Cione, A. L. \& Pereira, S. M. 1987. Los peces del Jurásico de Argentina. El Jurásico anterior a los movimientos intermálmicos. In Volkheimer, W. (ed.). Bioestratigrafía de los Sistemas Regionales del Jurásico y el Cretácico de América del Sur, Vol. 1: 287-298, CRICYT, Mendoza.

Cortiñas, J. S. 1996. La cuenca de Somuncurá - Cañadón Asfalto: sus límites, ciclos evolutivos del relleno sedimentario y posibilidades exploratorias. - XIII Congreso Geológico Argentino y III Congreso de Exploración de Hidrocarburos, Actas 1: 147-163.

Figari, E. G. \& Courtade, S. F. 1993. Evolución tectosedimentaria de la Cuenca de Cañadón Asfalto, Chubut, Argentina. - XII Congreso Geológico Argentino y II Congreso de Exploración de Hidrocarburos, Actas 1: 66-77.

Ford, D. \& Golonka, J. 2003. Phanerozoic paleogeography, paleoenvironment and lithofacies maps of the circumAtlantic margins. - Marine and Petroleum Geology 20: 249-285.

Foster, J. R. 2003. Paleoecological analysis of the vertebrate fauna of the Morrison Formation (Upper Jurassic), Rocky Mountain Region, USA. - Bulletin of the New Mexico Museum of Natural History \& Science 23: 1-95.

Fraas, E. 1908. Ostafrikanische Dinosaurier. - Palaeontographica 55: 105-144.

Gilmore, C. W. 1936. Osteology of Apatosaurus, with special reference to specimens in the Carnegie Museum. - Memoirs of the Carnegie Museum 11 (4): 175-271.

Gradstein, F. M., Ogg, J. G., Smith, A. G., Agterberg, F. P., Bleeker, W., Cooper, R. A., Davydov, V., Gibbard, P., Hinnov, L. A., House, M. R., Lourens, L., Luterbacher, H. P., McArthur, J., Melchin, M. J., Robb, L. J., Shergold, J., Villeneuve, M., Wardlaw, B. R., Ali, J., Brinkhuis, H., Hilgen, F. J., Hooker, J., Howarth, R. J., Knoll, A. H., Laskar, J., Monechi, S., Plumb, K. A., Powell, J., Raffi, I., Röhl, U., Sadler, P., Sanfilippo, A., Schmitz, B., Shackleton, N. J., Shields, G. A., Strauss, H., Van Dam, J., van Kolfschoten, T., Veizer, J. \& Wilson, D. 2004. A geologic time scale 2004. 589 pp., Cambridge University Press, Cambridge.

Holland, W. J. 1915. A new species of Apatosaurus. - Annals of the Carnegie Museum 10: 143-145.

Hulke, J. W. 1874. Note on a very large saurian limb-bone adapted for progression upon land, from the Kimmeridge Clay of Weymouth, Dorset. - Quarterly Journal of the Geological Society of London 30: 16-17.

- 1887. Note on some dinosaurian remains in the collection of A. Leeds, Esq., of Eyebury, Northamptonshire. Quarterly Journal of the Geological Society of London 43: $695-702$.

Janensch, W. 1914. Übersicht über die Wirbeltierfauna der Tendaguruschichten, nebst einer kurzen Charakterisierung der neu aufgeführten Arten von Sauropoden. - Archiv für Biontologie 3 (1): 81-110.

- 1950. Die Wirbelsäule von Brachiosaurus brancai. - Palaeontographica, Supplement 7 (I, 3): 27-93.

- 1961. Die Gliedmaszen und Gliedmaszengürtel der Sauropoden der Tendaguru-Schichten. - Palaeontographica, Supplement 7 (I, 3): 177-235.

Jensen, J. A. 1985. Three new sauropod dinosaurs from the Upper Jurassic of Colorado. - Great Basin Naturalist 45: 697-709.

Langston, W. \& Durham, J. W. 1955. A sauropod dinosaur from Columbia. - Journal of Paleontology 29 (6): 10471051.

Lapparent, A. F. d. \& Zbyszewski, G. 1957. Les Dinosauriens du Portugal. - Mémoire de Services Géologiques du Portugal (Nouvelle Série) 2: 1-63.

López-Arbarello, A. 2004. The record of Mesozoic fishes from Gondwana (excluding India and Madagascar). In Arratia, G. \& Tintori, A. (eds). Mesozoic Fishes 3 - Sys- 
tematics, Paleoenvironments and Biodiversity: 597-624, Verlag Dr. Friedrich Pfeil, Munich.

López-Arbarello, A., Arratia, G. \& Cordoniú, L. 2002. Coccolepids from South America and the early history of Chondrostei. - Journal of Vertebrate Paleontology 22 (suppl. to 3): $80 \mathrm{~A}-81 \mathrm{~A}$.

Marsh, O. C. 1896. The dinosaurs of North America. - Sixteenth Annual Report of the United States Geological Survey 1994-95: 133-244.

Martin, T. \& Rauhut, O. W. M. 2005. Mandible and dentition of Asfaltomylos patagonicus (Australosphenida, Mammalia) and the evolution of tribosphenic teeth. - Journal of Vertebrate Paleontology 25 (2): 414-425.

McIntosh, J. S. 1990. Sauropoda. In Weishampel, D. B., Dodson, P. \& Osmólska, H. (eds). The Dinosauria: 345-401, University of California Press, Berkeley.

McIntosh, J. S., Miller, W. E., Stadtman, K. L. \& Gillette, D. D. 1996. The osteology of Camarasaurus lewisi (Jensen, 1988). - Brigham Young University Geology Studies 41: $73-115$.

Musacchio, E. A., Beros, C. \& Pujana, I. 1990. Microfósiles continentales del Jurásico y el Cretácico en Chubut y su contribución a la bioestratigrafia de la Cuenca del Golfo San Jorge, Argentina. In Volkheimer, W. (ed.). Bioestratigrafía de los Sistemas Regionales del Jurásico y el Cretácico de América del Sur, Vol. 2: 355-383, CRICYT, Mendoza.

Osborn, H. F. \& Mook, C. C. 1921. Camarasaurus, Amphicoelias, and other sauropods of Cope. - Memoirs of the American Museum of Natural History 3 (3): 247-287.

Page, R., Ardolino, A., de Barrio, R. E., Franchi, M., Lizuain, A., Page, S. \& Nieto, D. S. 1999. Estratigrafía del Jurásico y Cretácico del Macizo de Somún Curá, Provincias de Río Negro y Chubut. In Caminos, R. (ed.). Geología Argentina: 460-488, Subsecretaría de Minería de la Nación, Buenos Aires.

Proserpio, C. A. 1987. Descripción geológica de la Hoja 44 e, Valle General Racedo, Pcia. del Chubut. - Dirección Nacional de Minería y Geología, Boletín 201: 1-102.

Raath, M. A. \& McIntosh, J. S. 1987. Sauropod dinosaurs from the central Zambesi valley, Zimbabwe, and the age of the Kadzi Formation. - South African Journal of Geology 90 (2): 107-119.

Rauhut, O. W. M. 2002. Dinosaur evolution in the Jurassic: A South American perspective. - Journal of Vertebrate Paleontology 22 (suppl. to 3): 89A.

- 2003. A dentary of Patagosaurus (Sauropoda) from the Middle Jurassic of Patagonia. - Ameghiniana 40 (3): $425-432$.

- 2005. Osteology and relationships of a new theropod dinosaur from the Middle Jurassic of Patagonia. - Palaeontology 48 (1): 87-110.

Rauhut, O. W. M., López-Arbarello, A., Puerta, P. \& Martin, T. 2001. Jurassic vertebrates from Patagonia. - Journal of Vertebrate Paleontology 21 (suppl. to 3): 91A.

Rauhut, O. W. M., Martin, T., Ortiz-Jaureguizar, E. \& Puerta, P. 2002. A Jurassic mammal from South America.Nature 416: $165-168$.

Rauhut, O. W. M. \& Puerta, P. 2001. New vertebrate fossils from the Middle-Late Jurassic Cañadon Asfalto Formation of Chubut, Argentina. - Ameghiniana 38 (4, Suplemento): $16 \mathrm{R}$.

Rauhut, O. W. M., Remes, K., Fechner, R., Cladera, G. \& Puerta, P. 2005. Discovery of a short-necked sauropod dinosaur from the Late Jurassic period of Patagonia. Nature 435: 670-672.

Rich, T. H., Vickers-Rich, P., Gimenez, O., Cúneo, R., Puerta, P. \& Vacca, R. 1999. A new sauropod dinosaur from Chubut Province, Argentina. - National Science Museum Monographs 15: 61-84.

Riggs, E. S. 1903. Brachiosaurus altithorax, the largest known dinosaur. - American Journal of Science (ser. 4) 15: 299_ 306.
- 1904. Structure and relationships of opisthocoelian dinosaurs. Part II. The Brachiosauridae. - Field Columbian Museum Publications, Geological Series 2 (6): 229-247.

Salgado, L. 2001. Los Saurópodos de Patagonia: sistemática, evolución y paleobiología. In Actas de las II Jornadas de Paleontología de Dinosaurios y su Entorno: 139-168, Salas de los Infantes, Burgos.

Salgado, L., Coria, R. A. \& Calvo, J. O. 1997. Evolution of titanosaurid sauropods. I: Phylogenetic analysis based on the postcranial evidence. - Ameghiniana 34 (1): $3-32$.

Sereno, P. C., Beck, A. L., Dutheil, D. B., Larsson, H. C. E., Lyon, G. H., Moussa, B., Sadleir, R. W., Sidor, C. A., Varricchio, D. J., Wilson, G. P. \& Wilson, J. A. 1999. Cretaceous sauropods from the Sahara and the uneven rate of skeletal evolution among dinosaurs. - Science 286: $1342-1347$.

Silva Nieto, D. G., Cabaleri, N. G. \& Salani, F. M. 2003. Estratigrafía de la Formación Cañadón Asfalto (Jurásico Superior), provincia del Chubut, Argentina. - Ameghiniana 40 (4, Suplemento): 46R

Silva Nieto, D. G., Cabaleri, N. G., Salani, F. M. \& Coluccia, A. 2002. Cañadón Asfalto, una cuenca tipo "pull apart" en el área de Cerro Cóndor, provincia del Chubut. - XV Congreso Geológico Argentino, El Calafate, Acta 1: $238-244$.

Smith, A. G., Smith, D. G. \& Funnell, B. M. 1994. Atlas of Mesozoic and Cenozoic coastlines. 99 pp., Cambridge University Press, Cambridge.

Swofford, D. L. 2003. PAUP*. Phylogenetic Analysis Using Parsimony (*and other methods). Version 4. - Sinauer Associates, Sunderland, Massachusetts.

Tasch, P. \& Volkheimer, W. 1970. Jurassic conchostracans from Patagonia. - University of Kansas, Paleontological Contributions 50: 1-23.

Turner, J. C. 1983. Descripción geológica de la Hoja 44d, Colan Conhué. - Dirección Nacional de Minería y Geología, Boletín 197: 1-78.

Unwin, D. M., Rauhut, O. W. M. \& Haluza, A. 2004. The first "rhamphorhynchoid" from South America and the early history of pterosaurs. In Reitner, J., Reich, M. \& Schmidt, G. (eds). Geobiologie. 74. Jahrestagung der Paläontologischen Gesellschaft, Göttingen, 02. bis 08. Oktober 2004. Kurzfassungen der Vorträge und Poster: 235-237, Universitätsdrucke Göttingen, Göttingen.

Upchurch, P. 1998. The phylogenetic relationships of sauropod dinosaurs. - Zoological Journal of the Linnean Society 124: 43-103.

Upchurch, P., Barrett, P. M. \& Dodson, P. 2004. Sauropoda. In Weishampel, D. B., Dodson, P. \& Osmólska, H. (eds). The Dinosauria. Second Edition: 259-322, University of California Press, Berkeley.

Upchurch, P., Hunn, C. A. \& Norman, D. B. 2002. An analysis of dinosaurian biogeography: evidence for the existence of vicariance and dispersal patterns caused by geological events. - Proceedings of the Royal Society of London B 269: 613-621.

Upchurch, P. \& Martin, J. 2003. The anatomy and taxonomy of Cetiosaurus (Saurischia, Sauropoda) from the Middle Jurassic of England. - Journal of Vertebrate Paleontology 23 (1): 208-231.

Upchurch, P., Tomida, Y. \& Barrett, P. M. 2004. A new specimen of Apatosaurus ajax (Sauropoda: Diplodocidae) from the Morrison Formation (Upper Jurassic) of Wyoming, USA. - National Science Museum Monographs 26: $1-108$.

Weishampel, D. B., Barrett, P. M., Coria, R. A., Le Loeuff, J., Xu, X., Zhao, X., Sahni, A., Gomani, E. M. P. \& Noto, C. R. 2004. Dinosaur distribution. In Weishampel, D. B., Dodson, P. \& Osmólska, H. (eds). The Dinosauria. Second Edition: 517-606, University of California Press, Berkeley. 
Wilson, J. A. 2002. Sauropod dinosaur phylogeny: critique and cladistic analysis. - Zoological Journal of the Linnean Society 136: $217-276$.

Wilson, J. A. \& Sereno, P. C. 1998. Early evolution and higher-level phylogeny of sauropod dinosaurs. - Society of Vertebrate Paleontology, Memoir 5: 1-68.

Zambrano, J. J. 1987. Las cuencas sedimetarias de América del Sur durante el Jurásico y Cretácico: su relación con la actividad tectónica y magmática. In Volkheimer, W. (ed.). Bioestratigrafía de los Sistemas Regionales del Jurásico y el Cretácico de América del Sur, Vol. 1: 1-48, CRICYT, Mendoza.

\section{Appendix}

Additional information regarding the phylogenetic analysis of the specimens described here:

Codings of the specimens MPEFPV 3098 and 3099 in the matrix of Wilson (2002):

\section{MPEF PV 3098}

????? ????? ????? ????? ????? ????? ????? ????? ?????

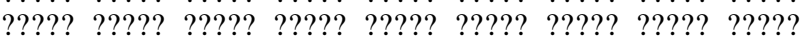
????? ????? ????? ????? ????? ????? ????? ????? ?????

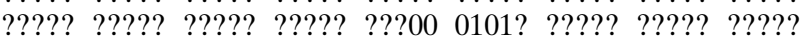
????? ????? ????? ????? ????? ????? ????? ????? ????? ????? ????

\section{MPEF PV 3099}

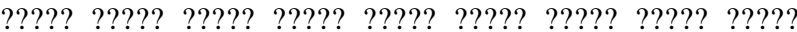
????? ????? ????? ????? ????? ????? ????? ????? ????? ????? ????? ????? ????? ??0?? ??000 00??? $010000000 ?$ ????? ????1 0???? ????? ????? ????? ????? ????? ????? ????? ???21 ????? ????? ????? ????? ????? ????? ????? ????? ????

Three characters have been added to the analysis: Neural arches in mid-caudal vertebrae: placed approximately on the middle of the centrum (0) - displaced anteriorly (1)

First caudal chevron: Y-shaped (0) - V-shaped (1)

Expansion of lateral margin of proximal end of humerus: strongly developed $(0)$ - expansion reduced or absent, lateral margin almost straight proximally (1)

Additional codings of the three new characters:

Prosauropoda:

Theropoda:

Vulcanodon:

Barapasaurus:

Omeisaurus:

Shunosaurus:

Patagosaurus:

Mamenchisaurus:

Apatosaurus:

Barosaurus:

Brachiosaurus:

Camarasaurus:

Dicraeosaurus:

Diplodocus:

Haplocanthosaurus:

Amargasaurus:

Euhelopus:

Jobaria:

Malawisaurus:

Nigersaurus:

Limaysaurus:

Rebbachisaurus:

Alamosaurus:

Nemegtosaurus:

Neuquensaurus:

Opisthocoelicaudia:

Rapetosaurus:

Saltasaurus:

Isisaurus:

MPEF PV 3098:

MPEF PV 3099:

Furthermore, a second state has been added to Wilson's character no. 189: Pubis, ambiens process development: small, confluent with (0), prominent, projecting anteriorly from the anterior margin of the pubis (1), or marked by a low step, with anterior margin of pubis straight proximally (2)

Character state 2 has been coded for Brachiosaurus, Haplocanthosaurus, and MPEF PV 3099.

Finally, one coding error in the matrix of Wilson (2002) has been corrected: character 160 (deltopectoral crest of humerus prominent or reduced) has been coded as "0" in Brachiosaurus, since the deltopectoral crest is prominent in this taxon, as correctly coded by Wilson \& Sereno (1998) and Upchurch et al. (2004). 